\title{
Project-based Learning Method in Advanced Mathematics for Engineering Students in Vietnam: Experimental Research
}

\author{
Tran Viet Cuong ${ }^{1, *}$, Nguyen Van Tuan ${ }^{2}$ \\ ${ }^{1}$ Thai Nguyen University of Education, Vietnam \\ ${ }^{2}$ Hanoi University of Industry, Hanoi City, Vietnam
}

Received December 27, 2020; Revised February 1, 2021; Accepted March 1, 2021

\section{Cite This Paper in the following Citation Styles}

(a): [1] Tran Viet Cuong, Nguyen Van Tuan, "Project-based Learning Method in Advanced Mathematics for Engineering Students in Vietnam: Experimental Research," Universal Journal of Educational Research, Vol. 9, No. 3, pp. 528-539, 2021. DOI: 10.13189/ujer.2021.090312.

(b): Tran Viet Cuong, Nguyen Van Tuan (2021). Project-based Learning Method in Advanced Mathematics for Engineering Students in Vietnam: Experimental Research. Universal Journal of Educational Research, 9(3), 528-539. DOI: 10.13189/ujer.2021.090312.

Copyright $\mathrm{C} 2021$ by authors, all rights reserved. Authors agree that this article remains permanently open access under the terms of the Creative Commons Attribution License 4.0 International License

\begin{abstract}
Mathematics and other sciences are considered difficult subjects by the majority of students. One of the reasons is that in the traditional classroom students are taught theory first and then they are asked to solve some exercises with algorithms, use less inference and rarely connect with activities in the real world. In the process of innovating teaching and learning methods, the use of project-based learning methods (PBL) has become popular in teaching and learning in universities in many countries around the world. This article uses the empirical research method with the application of project-based learning in the classroom at Hanoi Industrial University. The purpose of the study is to help students apply their knowledge and practical skills to participate in solving problems "The Robot Control Design Project". Research method: we talk with all the students in the class about the purpose of the project is to The Robot Control Design Project; Data collection method includes survey information from implemented projects and self-assessment of project-based learning of 48 third-year technical students at Hanoi Industrial University. The results show that students evaluate PBL positively because this method helps students have interesting practical experiences, while developing collaborative skills, problem solving and self-control in study. The results of the article can be used as a basis for future research in engineering classes to meet the increasing needs of learners
\end{abstract}

for international integration.

Keywords Project-based Learning Method, Construction, Experiment

\section{Introduction}

There have been significant fundamental changes in teaching and learning in universities in Vietnam in the past decade, in which, enhancing the role of the experimental process is commonly applied in teaching and learning in Engineering. Although these changes help learners become more active in the learning process, learners have not really mastered the learning process. The learner-centered approach in teaching and learning in Vietnam has not been fully applied and traditional teaching methods still exist when the teacher is still the main source of knowledge and the knowledge creation role of learners in the teaching process has not really been paid attention [1], [2].

In the era of globalization, learners have to master the process of acquiring knowledge for international integration, traditional teaching methods are no longer suitable when learners need to "learn with practice", construct and share knowledge, positive experience and real learning situations [3], [4], [5], [6], [7], [8]. One of the 
most innovative methods of teaching and learning in an engineering class is using Project Based Learning (PBL).

According to Jason Ravitz, Nate Hixson, Mary English, John Megendoller (2012) [9], PBL provides opportunities for students to learn deeply content knowledge and 21st century skills. While PBL practices vary depending on grade level and subject area, projects should allow some level of student voice and choice, and must be planned, managed, and evaluated carefully to connect rigorously academic content to the 21 st century Skills (such as collaboration, communication, and critical thinking) through students' products and presentations [10], [11].

PBL method can meet the requirements of learners for the process of building knowledge and practical experience; however, this method is still quite new and is not yet popular in teaching and learning technical majors in Vietnam. Therefore, this article applies project-based teaching methods in Advanced Maths for students in engineering to help students not only have theoretical understanding but also practical experience, develop collaboration skills, problem solving skill and self-regulation in learning, thereby improving autonomy in learning.

\section{Literature Reviews}

\subsection{The Concept of Project-based Learning Method}

PBL has become popular in teaching and learning in many countries around the world, such as teaching about traditional culture, teaching preserving intangible heritages, teaching about ecological environmental protection, etc. In the context of technical teaching, PBL is used equivalent to many different terms such as project work, project method, project approach, project-oriented approach, project-based instruction [12] or experiential learning [14], [13].

PBL is simply defined as a learning strategy organized with learning projects [15], [16], [17]. Buck Institute of Education [18a], Blumenfeld, Fishman, Krajcik, Marx and Soloway (2000) [6], an American research and development organization, defines PBL as "a teaching method in which learners acquire knowledge and skills by working for a long period of time to study and answer a real, compelling, complex question, problem, or challenge".

\subsection{Characteristics of Project-based Learning Method}

Thomas [15] raised 5 criteria of PBL including: (1) centrality; (2) motivation; (3) tectonics; (4) autonomy in learning and (5) reality. The uniqueness of PBL is the construction of a final product that shows the learners' knowledge, understanding and attitude towards the problem being researched and that the problem is presented by the learner in many different forms such as videos, pictures, reports, models and other artifacts [18].
According to Cocco [19], PBL is a learner-centered approach, based on three constructivist principles: context-specific learning, active learning, and sharing knowledge and understanding. During the PBL process, learners are given the opportunity to "build knowledge by solving real world problems through questioning and discussing, designing and conducting investigation, gathering, analyzing and explaining information, data, draw conclusions and report results "[21]. Teaching in this form of questioning allows learners to gain meaningful learning experiences and achieve a common goal through collaborative development and presentation of a final product [20]. PBL is also a form of experiential learning, in which learners participate consciously and actively think about the learning process [22], [23]. The Robot Control Design projects in this experimental study demonstrate the above characteristics of PBL.

\subsection{The Benefits of Project-based Learning}

Project-based learning method brings many practical benefits to learners. First of all, PBL helps promote learners' self-regulation learning in the process of systematically documenting and thinking [24]. PBL helps learners gain autonomy through goal setting, planning and organization and become more excited about learning [25]. Thus, PBL contributes to the development of learners' autonomy capacity in learning.

In addition, PBL also creates conditions for learners to develop collaboration skills. Collaboration skills are central to the teaching and learning process [26]. PBL offers learners the opportunity to "interact and communicate with each other ... in a real context" [27]. Markham [28] thinks that collaboration skills in PBL are similar to teamwork skills in professions; this will help learners to equip them with effective teamwork skills, which will help them work better in future work.

In particular, PBL helps learners develop high-level problem solving and critical thinking skills [29]. These are very important, transformable, lifelong skills that learners always need outside of the classroom. The ability of learners to solve problems formed during project design and construction helps learners participate more actively in the learning process thanks to increased awareness [30]. Because PBL consists of highly practical work, it is more meaningful to learners in increasing the learners' interest and motivation to participate in the project and to promote learning [31].

\section{Research Methods}

In order to promote PBL's preeminence in teaching and learning engineering, an empirical study on PBL was conducted with 48 third-year engineering students of Hanoi Industrial University. The Robot Control Design Project was selected as an experimental research for the 
following reasons: (1) the survey subjects were third-year students with knowledge of theory and practice from a basic level or higher; (2) The author of the article who is also a lecturer of this module can evaluate his own teaching method through research on his own teaching activities.

\subsection{Research Questions}

The empirical study answers the following questions:

(1) How do students work on robot control design projects?

(2) What is the student's experience with the project-based learning method?

To answer the research questions above, robot control design projects are conducted with student groups for 10 weeks during a semester. The students participating in the study were divided into 4 groups, each group of 12 students. To delve deeply into the topic of robotic control design, groups of students choose their own ideas of whether to build or improve certain related equipment to carry out the project.

\subsection{Implementing Project}

To achieve the goals of PBL, the robot control design project consists of 4 specific implementation steps. We recommended a number of steps to implement a project because "when the projects are structured to help students actively plan projects early, students gradually develop a sense of ownership and pride in project". Therefore, students are instructed in detail about 4 steps to implement a robot control design project from group formation, topic selection to information research on topic, group work, and correct the trainer's responses, present the final product to the class, and evaluate the project. To avoid selecting the same topic, all of the groups have to apply for a project topic before working on their robot control design project.

Steps to implement robot control design project

Instruction: Students do a robot control design project for 10 weeks in the following stages (Diagram 1).

\section{Steps:}

\section{Step 1: Project construction}

Teachers and students propose ideas on the topic of Robot Control Design for a learning project by presenting a situation with a real problem or a task to solve. The project can be proposed by a teacher, student or student group, but it is the student who decides to choose, however, it should be ensured that the content is suitable for the purpose of learning, the content of the program and the facts, in accordance with the capacity of students. The teacher can also recommend a number of topics for students to choose from.

Students clearly define the goals of the Robot Control Design project, the requirements to be achieved of the project.

Teachers divide groups or let students group themselves to suit the task of the Robot Control Design project, according to the capacity of each student.

\section{Step 2: Make an implementation plan}

Students actively discuss project goals, tasks to be performed in the project, then divide the work into small packages for each group or individual to take on a part of the work. Tasks of each group and individual must be very specific and detailed about the content of the work, how to proceed, and the time of completion.

Basing on project goals, project implementation time funds and student deployment plans teachers give comment, and correct to help students implement in the right direction.

\section{Step 3: Project implementation}

During this period, groups of students positively and actively perform assigned tasks by applying the knowledge learned and self-researching.

With the feature of Advanced Math for engineering, in order to carry out the Robot Control Design project, students need to know about other basic knowledge related to the project such as mechanics, electricity. Therefore, acquiring relevant specialized knowledge is an important task in project implementation.

While working on a learning project, students need to increase communication between team members, between group and group. Members of the group or between groups always have opinions of each other's feedback, strengthening cooperation and exchange among team members, between groups. Especially, when doing projects, students always have to review the goals for timely adjustments.

Teachers always supervise and adjust students' activities so that all activities go according to plan, set targets, and ensure time progress.

During the project implementation phase, the qualities and abilities of the students are revealed and developed. 


\section{MATHEMATICS ACTIVITIES}

\section{Develop a set of directional questions related to the robot control design project}

Essential Question: Laplace transforms and their applications?

Unit Question: What is Laplace transform? What is the purpose of the Laplace transformation? What Laplace transformations are there? How to apply Laplace transforms in real problems?

Content question:

Question 1: What is the concept of the Laplace transformation?

Question 2: What are the basic Laplace transformations?

Question 3: Applying to Laplace of electrical circuits?

Question 4: An electrical circuit in the robot control contains $1 \mathrm{R}$ element and $1 \mathrm{~L}$ element in series with a source as shown in the figure. When the switch is closed $=0, u_{C}(0)=1 \mathrm{~V}$. Find the current $\mathrm{i}(\mathrm{t})$ in the circuit above to control the normal operation? (Figure 1)

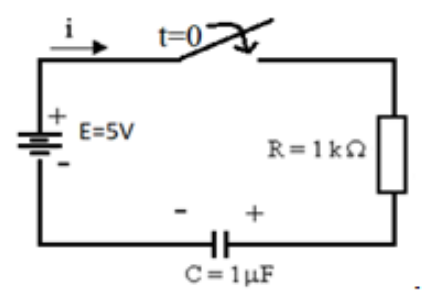

Figure 1. An electrical circuit in the robot control contains $1 \mathrm{R}$ element and $1 \mathrm{C}$ element in series

Question 5: Apply the Laplace transform to find the current $\mathrm{i}(\mathrm{t}), \mathrm{t}>0$ in the circuit of the controlling robot and design and assemble the robot control that know the parameters $E=10 \cdot \sin (5 t)(V), R=4 \Omega$ và $L=2 H$. Suppose at $\mathrm{t}=0$, when the lock is closed, there is no current, that is $i_{0}=i(0)=0, t=0$. (Figure 2).

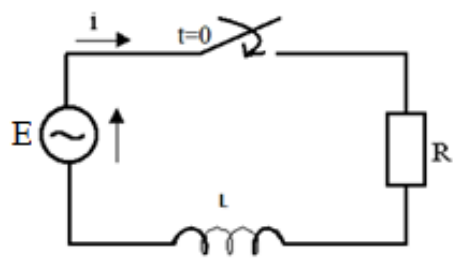

Figure 2. An electrical circuit in the robot control contains $1 \mathrm{R}$ element and $1 \mathrm{~L}$ element in series

Question 6: What is a practical problem that leads to Laplaceization?

Question 7: (Question of navigation) How is the Fourier transform applied in some areas such as signal processing, cryptography, frequency?

\section{Implement a robot control design project}

\section{Task 1: Students research theory-driven theory}

Students in the research groups answer the content questions (questions 1,2,3) by writing their answers on the ballots. Under the organization of the group leader, group members exchange answer sheets for each other and then exchange ideas. After that, the group leader discussed and summarized on A0 paper.

\section{Task 2: Research and answer content questions 4.}

After studying the conceptual system and Laplace transforms, the groups work in the following order:

+ Each person should think to solve the above problem and write a draft;

+ Pass the draft paper to other people to see in a circle and make suggestions, whether the solution is complete or not;

+ Discuss in groups and give solutions to their groups; 
+ Teachers follow up the working groups and provide support when needed.

The solution is summarized as follows:

Apply Kirchhoff's law to the above circuit

$$
E=u_{R}(t)+u_{C}(t)=R i(t)+u_{C}(0)+\frac{1}{C} \int_{0}^{t} i(t) d t .
$$

Replace the number we get

$$
1+\frac{1}{10^{-6}} \int_{0}^{t} i(t) d t+10^{3} i(t)=5
$$

Multiply the 2 sides of the equation above by $10^{-6}$, we have

$$
\int_{0}^{t} i(t) d t+10^{-3} i(t)=4 \times 10^{-6}
$$

Laplace 2 sides of the equation above we have obtained

$$
\frac{I(s)}{s}+10^{-3} I(s)=\frac{5 \times 10^{-6}}{s} .
$$

So we have

$$
\left(\frac{1}{s}+10^{-3}\right) I(s)=\frac{4 \times 10^{-6}}{s} .
$$

Multiply the 2 sides of the equation by $s:\left(1+10^{-3} s\right) I(s)=4 \times 10^{-6}$.

Hearby, we have:

$$
I(s)=\frac{4 \times 10^{-6}}{1+10^{(-3)} s} \text {. So } \quad i(t)=4 \times 10^{-3} e^{-1000 t} A . \text { Graph } i(t)=4 \times 10^{-3} e^{-1000 t} A .
$$

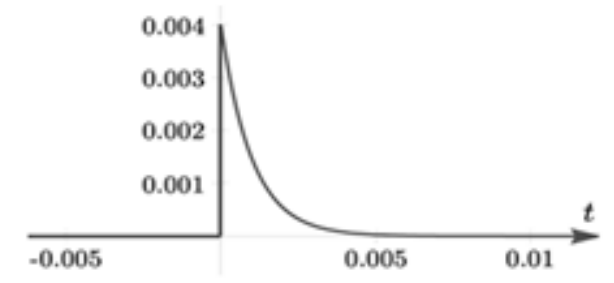

Figure 3. The graph of $i(t)=4 \times 10^{-3} e^{-1000 t} A$.

\section{Task 3: Research and answer content questions 5}

To answer content question 5, students must be sure of what they have researched before. The method of organizing the implementation is the same as when performing task 2. In groups, divide it into pairs. Each person in the pair thinks about and drafts in a short time; exchanges drafts for each other, then comment, edit and agree on group the content answers.

The solution is summarized as follows:

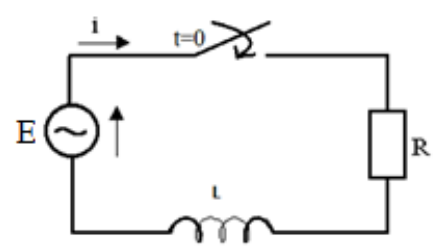

Figure 4. An electrical circuit in the robot control contains $1 \mathrm{R}$ element and $1 \mathrm{~L}$ element in series 
Apply Kirchhoff's law to the above circuit (Figure 4), we get

$$
R i(t)+L \frac{d i(t)}{d t}=E,
$$

Replace the number in the equation above, we get

$$
4 i(t)+2 \frac{d i(t)}{d t}=10 \sin (5 t)
$$

Laplace 2 sides of the equation above we have obtained

$$
4 I(s)+2(s I(s)-i(0))=10 \frac{5}{\left(s^{2}+25\right)} .
$$

According to the original condition $i_{0}=i(0)=0$. From above we have obtained

$$
4 I(s)+2 s I(s)=\frac{50}{\left(s^{2}+25\right)}
$$

We have

$$
I=\frac{25}{(s+2)\left(s^{2}+25\right)}=\frac{A}{s+2}+\frac{B s+C}{s^{2}+25}
$$

So, we must have

$$
25=A\left(s^{2}+25\right)+(B s+C)(s+2)
$$

We need to find $A, B$ and $C$. From the equation $(*)$ we obtain

$$
A=\frac{25}{29}, \quad B=-\frac{25}{29}, \quad C=\frac{50}{29} \text {. }
$$

Therefore,

$$
\begin{gathered}
I(s)=\frac{25}{(s+2)\left(s^{2}+25\right)} \\
=\frac{25}{29(s+2)}-\frac{25}{29} \frac{s}{s^{2}+25}+\frac{50}{29} \frac{1}{s^{2}+25} \\
=\frac{25}{29}\left(\frac{1}{s+2}-\frac{s}{s^{2}+25}+\frac{2}{5} \frac{5}{s^{2}+25}\right) .
\end{gathered}
$$

Using the Laplace transform we found

$$
i(t)=\frac{25}{29}\left[e^{-2 t}-\cos (5 t)+\frac{2}{5} \sin (5 t)\right] A .
$$

Graph

$$
i(t)=\frac{25}{29}\left[e^{-2 t}-\cos (5 t)+\frac{2}{5} \sin (5 t)\right] A .
$$

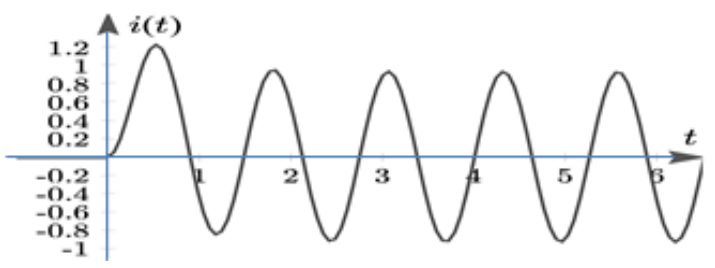

Figure 5. The graph of $i(t)=\frac{25}{29}\left(e^{-2 t}-\cos 5 t+\frac{2}{5} \sin 5 t\right) A$.

Regarding the robot control product, the groups operate as follows:

- Groups assign tasks to each individual in the group;

- Calculate and design electrical circuit diagrams;

- Prepare components such as battery source, capacitors, conductors, resistors;

- After discussing for the whole group, the groups assemble the controller in the practice room. 
- Perform test operation of the controller.

\section{Task 4: What is a practical problem that leads to Laplaceization?}

+ The groups have prepared, learned the actual problems in advance, one group represented to give the situation as required above, the remaining groups commented with or denied and gave their own opinion.

+ Role swap groups make comments and discuss some real-world situations.

+ When approved, the team leaders record satisfactory example cases and synthesize.

+ The groups agreed in their groups to edit the content and presentation form of the report, synthesize the complete content of the report; write a final report.

+ Checking progress and completing products: Teachers regularly supervise, inspect and urge groups, promptly give instructions and directions of activities. Group record, edit, and perfect their own work.

Question 7: Students learn to see the Fourier transform plays an important role in the problems of converting discrete signals into amplitude and frequency components, which have great significance in signal processing, cryptography ,... This is the direction of research in the next project of the program.

\section{Task 5: Present results and evaluation}

- The groups synthesize the results and present their reports to the class. The teacher can appoint any member of the group to stand before the class to report so that the teacher can comment on the results of the group activities are effective or not, other members follow up, get out personal review.

- The groups display the products were hand-held robotic controls, demonstrate the maneuverability of the controller.

Product requirements: Compact, solid, beautiful appearance. Scientific design circuit, sufficient power supply, capacitor, inductor, frequency generator. Solid welds, conductors. Low cost. Some product pictures (Figure 6)
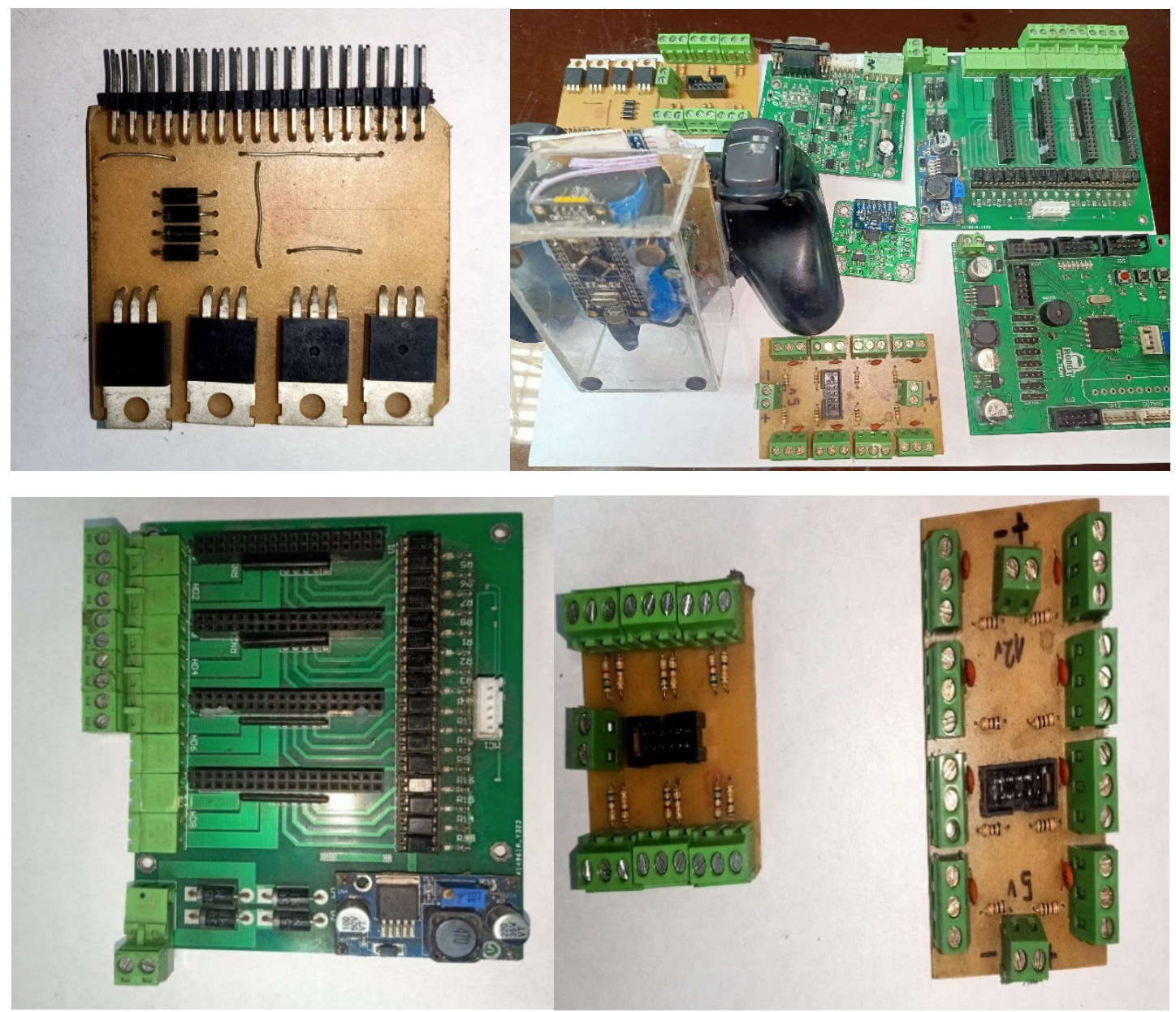

Figure 6. Product pictures 


\section{Step 4: Presenting results and reviews}

The result of the Robot Control Design project is a product that students can introduce and present to the groups or to the class.

Teachers prepare facilities such as computers, projectors, fonts, boards, ... so that students can introduce the results.

Evaluation of results can be made by individuals self-assessing the results of themselves, of groups, other individuals, or among groups of each other on the project implementation process, on the achieved products. The teacher is the last person to evaluate and make general comments on the project implementation and resulting products.
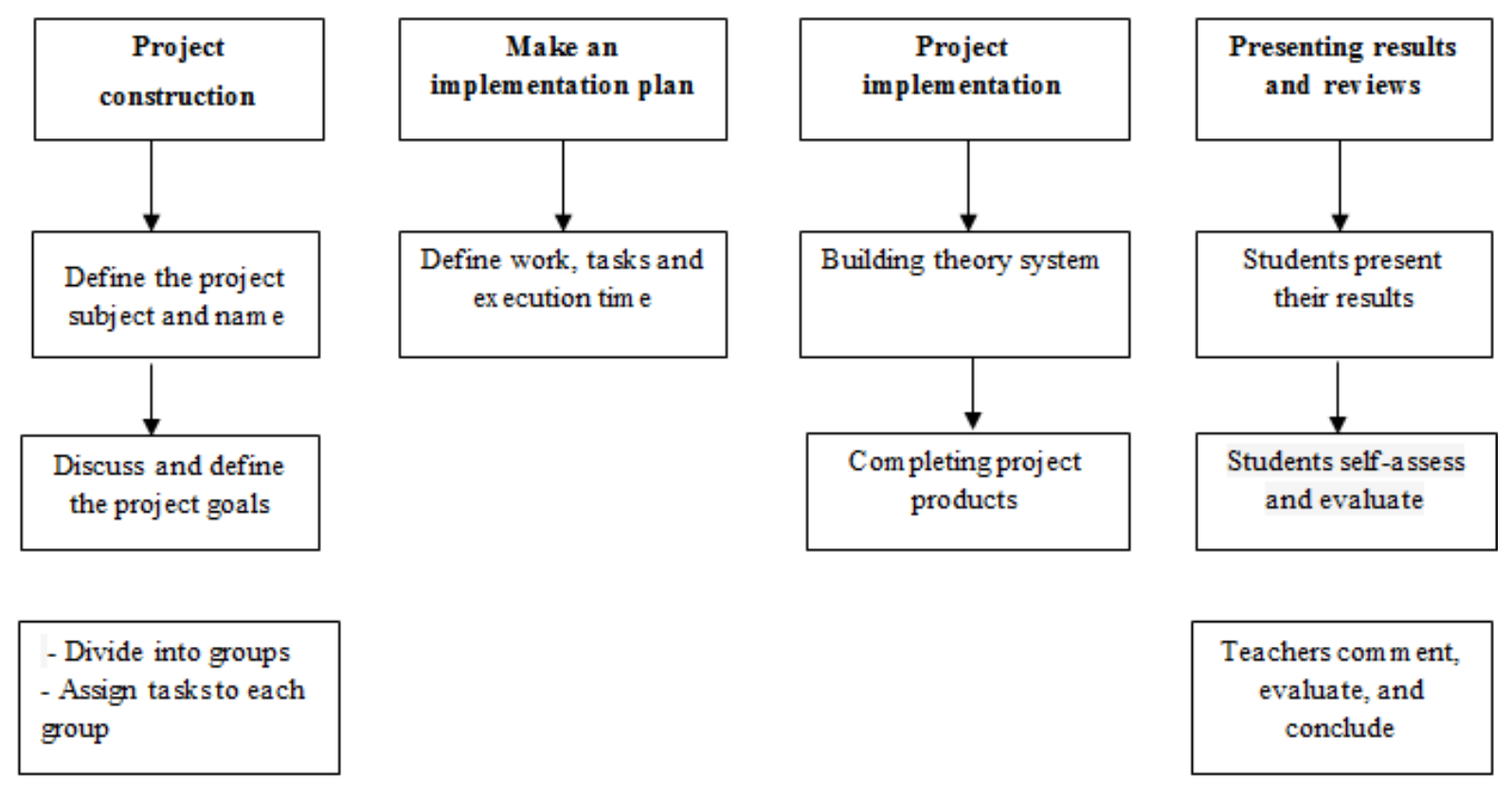
Teachers comm ent, evaluate, and conclude

Figure 1. Diagram of project implementation process

After presenting the robot control design project to class in week 10, all groups of students fill out a self-assessment survey of the project. This self-assessment consists of 10 questions, of which 8 closed questions refer to the student's experience with PBL on a 5-point Likert scale $(1=$ strongly disagree; $2=$ disagree; $3=$ neutral; $4=$ agree; $5=$ strongly agree), and 2 open-ended questions about students' problems and suggestions about PBL.

Table 1 contains questions for the purpose of studying self-assessment of groups of students participating in experimental research on project-based learning methods. Circle your opinion on questions 1-8 following the instructions below and state your opinion in sentences 9-10.

Table 1. Self-assessment questionnaire

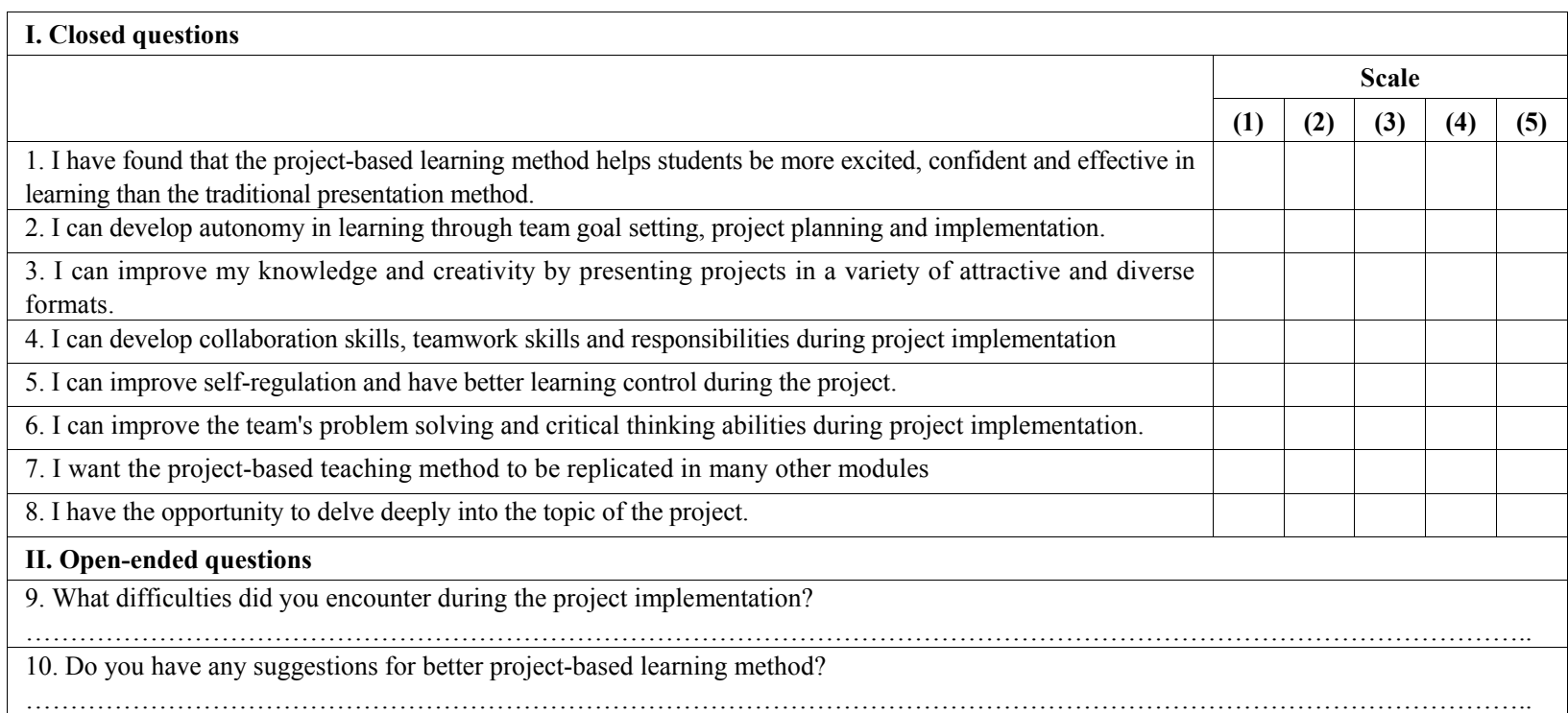




\subsection{Data analysis}

Regarding data analysis, descriptive methods are used to characterize robot control design projects. Quantitative analysis with calculation (one sample t-test) combined with qualitative analysis is applied to students' self-assessment of PBL.

\section{Result}

\subsection{Student Experience with Project-based Learning Methods}

After implementing related projects on robot control design, generally all groups of students have a positive assessment of PBL with an average value of 4 or more, which is statistically significant difference with $\mathrm{p}<.05$. (Table 2 ).

Table 2. Students make their own assessment of PBL (48 students)

\begin{tabular}{|c|c|c|c|}
\hline & $\begin{array}{l}\text { Mean value } \\
(\mathrm{M})\end{array}$ & $\begin{array}{c}\text { Standard deviation } \\
\text { (SD) }\end{array}$ & $\begin{array}{l}\text { t-test value } \\
(\mathrm{t})\end{array}$ \\
\hline $\begin{array}{l}\text { I have found that the project-based learning method helps students be more excited, confident and } \\
\text { effective in learning than the traditional presentation method. }\end{array}$ & 4,60 & 0,536 & 59,565 \\
\hline $\begin{array}{l}\text { I can develop autonomy in learning through team goal setting, project planning and } \\
\text { implementation. }\end{array}$ & 4,29 & 0,544 & 54,642 \\
\hline $\begin{array}{l}\text { I can improve my knowledge and creativity by presenting projects in a variety of attractive } \\
\text { and diverse formats. }\end{array}$ & 4,21 & 0,849 & 34,322 \\
\hline $\begin{array}{l}\text { I can develop collaboration skills, teamwork skills and responsibilities during project } \\
\text { implementation }\end{array}$ & 4,17 & 0,630 & 45,806 \\
\hline I can improve self-regulation and have better learning control during the project. & 4,10 & 0,627 & 45,347 \\
\hline $\begin{array}{l}\text { I can improve the team's problem solving and critical thinking abilities during project } \\
\text { implementation. }\end{array}$ & 4,06 & 0,783 & 35,948 \\
\hline I want the project-based teaching method to be replicated in many other modules & 3,94 & 0,633 & 43,119 \\
\hline I have the opportunity to delve deeply into the topic of the project. & 3,81 & 0,607 & 43,521 \\
\hline
\end{tabular}

Note: $\mathrm{p}^{*}=0,000$ difference with $\mathrm{p}<0.05 ; \mathrm{t}=\mathrm{t}$-test value of a sample; $\mathrm{p}=$ probability value

According to the results in Table 2, students agree the most that PBL helps students to be inspired, confident and learn more effectively than the traditional presentation method with the highest mean $(\mathrm{M}=4.60)$. With PBL's learner-centered approach, students find they have the opportunity to develop autonomy in learning through goal setting, group project planning, and implementation $(\mathrm{M}=$ 4.29).

The students all agreed on the benefits that PBL brought them through improving their ability to build knowledge and creativity $(\mathrm{M}=4.21 ; \mathrm{SD}=0.849 ; \mathrm{t}=34,322$ and $\mathrm{p}$ $<0.05$ ), develop collaborative skills, teamwork skills and responsibilities $(\mathrm{M}=4.17 ; \mathrm{SD}=0.630 ; \mathrm{t}=45,806 ; \mathrm{p}<0.05)$, improve self-regulation and control learning $(\mathrm{M}=4.10$; $\mathrm{SD}=0.627 ; \mathrm{t}=45,347$ and $\mathrm{p}<0.05)$ and improve problem solving abilities and critical thinking during project implementation $(\mathrm{M}=4,06 ; \mathrm{SD}=0.783 ; \mathrm{t}=35,948$ and $\mathrm{p}$ $<0.05$ ). The students also agreed to propose that the PBL should be replicated in many other modules $(\mathrm{M}=3.94$; $\mathrm{SD}=0.633 ; \mathrm{t}=43,119$ and $\mathrm{p}<0.05$ ). The average value of the opportunity for in-depth research on the project topic is the lowest $(\mathrm{M}=3.81 ; \mathrm{SD}=0.607 ; \mathrm{t}=43.521$ and $\mathrm{p}<0.05)$ due to the difficulties students face in project implementation process.

\subsection{Difficulties and Students' Proposals on PBL}

Although students appreciate PBL for the practical benefits that PBL brings, groups of students still have certain difficulties when implementing a robot control design project. First of all, PBL is completely new to students because they have never done a project before, except presentations in a traditional way. The challenge for the teams was to present a project related to designing a robot control. However, with the faculty input during project implementation, groups of students were able to self-adjust their projects by paying more attention to the presentation forms of the project combined with the specific products. In addition, at first, groups of students still had difficulty in the process of choosing a project topic because there was no consensus among the group. However, during the process of discussion, groups develop collaborative and teamwork skills, so the topic of groups is quickly agreed upon. Deeply researching the project topic is also a big challenge for groups of students who want to pick out the most prominent information about products of the project to present.

To carry out the robot control design project well, the groups made a number of constructive proposals.

Firstly, the project needs a lot of time to prepare the 
content and necessary tools and equipment. Therefore, students suggest groups need more time to improve the project after the teachers' feedback.

Second, to avoid groups focusing heavily on one problem, students suggest robot control design projects should cover multiple disciplines; that will bring more color and variety to projects.

Third, students lack resources to prepare projects except for information gathered online; therefore, students suggest that the school library needs to equip more resources about the technical disciplines of countries around the world so that they can use them for their robot control design projects better.

\section{Findings}

PBL is applied to the class at Hanoi Industrial University through robot control design projects that bring positive results in learning for students similar to the results of some previous studies [32], [33], [34], [35]. However, the practical benefits that robot control design projects bring to students in this study are shown in the following specific aspects.

\section{Building Knowledge}

With the learner-centered approach in PBL, learners play an important role in the knowledge building process. Duffy [36] thinks that learners' need to construct new knowledge is the key to acquiring and cultivating knowledge, not the requirements imposed by teachers. PBL has applied the central principles of constructivist approach to learning and problem solving in practical contexts: "learning is a dynamic process in which learners construct their knowledge through combining new ideas with existing knowledge" [37], [38]. Based on this approach, student groups have created knowledge to build the content of robot control design projects without the imposition of knowledge of the teacher; the teacher is only the instructor, or the person who gives feedback on student robot control design projects. With PBL, students are empowered to truly master the process of creating and sharing knowledge, so they feel more excited and confident in the learning process.

\section{Develop Collaboration and Teamwork Skills}

Robot control design projects help students develop collaborative and teamwork skills through unifying the selection of project topics, assigning tasks to each team member to build project content and design vivid visual tools. Collaboration and teamwork skills on robot control design projects are very helpful for students in the future as they help students "become seasoned teamworkers, proficient in making group action plan... work together to solve the problem "[26], [2], [39], [11].

\section{Autonomy in Learning}

Through the implementation of a robot control design project, groups of students can set goals, plan and organize the team's project implementation. In particular, from the faculty feedback on the team's draft project, groups of students used more effective learning strategies to adapt the project in a better way. They restructure the project, adjust the original plan and apply new strategies to create better project products. This shows that students have the ability to develop self-regulation and cognitive process control during the implementation of a robot control design project. This ability helps students to be more aware of their responsibilities in the learning process, thereby improving autonomy in learning [40].

\section{Experimental Learning}

PBL is a form of experiential learning with positive and real-world learning situations. Experimental learning "emphasizes the important role of learners' experiences in the learning process" [41]. In robot control design projects, groups of students participate in experiential learning by doing action learning [42] with content design, self-study, and manual installation of the devices of the project as well as technical calibration for the equipment. Therefore, the robot control design projects help students to have an interesting experience in making products for application in life. Active learning activities in robot control design projects helps students benefit from discoveries and experiences through observations, interactions, and real-world exploration [41]. This experience enriches the students' knowledge and life experience in future work.

\section{Conclusions}

This study provides empirical evidence on the use of PBL by student robot control design projects. Despite certain difficulties during project implementation, as it was the first-time students had been working on robot control design projects, the results showed that PBL offers many practical benefits and interesting experience for students, especially helps students build knowledge, improve collaboration and teamwork skills, improve self-regulation, control and develop autonomy in learning. These skills are very essential for learners and should be focused on developing so that students can integrate internationally in the age of globalization. In order to fully develop a learner-centered approach in PBL, teachers need to be more aware of the role of an instructor in student projects rather than as transmitting or imposing knowledge. Helping students overcome difficulties as well as responding to students' constructive suggestions when implementing projects, future PBL studies will surely bring about better results. From the practical benefits that PBL brings to students through robot control design projects, 
this study shows that PBL needs to be replicated and more popular in schools from high schools to universities in Vietnam to meet the increasingly high learning needs of learners for international integration.

\section{REFERENCES}

[1] Ministry of Education and Training Vietnam. "General Education Program 2018. Vietnam". 2018.

[2] Tran, C. V. "Organizing Project Based Teaching in the Training of Math Teachers in Vietnam," Revista Romaneasca pentru Educatie Multidimensionala, 9(2), 9-35, 2018.

DOI:

http://dx.doi.org/10.18662/rrem/2017.0902.01

[3] Sulaiman M. Al-Balushi \& Shamsa S. Al-Aamri-The effect of environmental science projects on students' environmental knowledge and science attitudes". International Research in Geographical and Environmental Education, 23:3, 213-227, 2014. DOI: $\underline{10.1080 / 10382046.2014 .927167}$

[4] Scott Wurdinger, Jean Haar, Robert Hugg and Jennifer Bezon $\AA-$-"A qualitative study using project-based learning in a mainstream middle school". Minnesota State University, Mankato, USA. Improving Schools (C) SAGE Publications, Vol. 10, No. 2, 150-161, 2007. ISSN 1365-4802 DOI: $10.1177 / 1365480207078048$

[5] Phyllis C. Blumenfeld, Elliot Soloway, Ronald W. Marx, Joseph S. Krajcik, Mark Guzdial \& Annemarie Palincsar"Motivating Project-Based Learning: Sustaining the Doing, Supporting the Learning". Educational Psychologist, 26:3-4, 369-398, 1991. DOI: 10.1080/00461520.1991.9653139

[6] Blumenfeld, P., Fishman, B.J., Krajcik, J., Marx, R.W. \& Soloway, E. - "Creating usable innovations in systemic reform: scaling up technology-embedded project-based science in urban schools". Educational Psychologist, 35(3), 149-164, 2000.

[7] Sulaiman M. Al-Balushi \& Shamsa S. Al-Aamri - "The effect of environmental science projects on students' environmental knowledge and science attitudes". International Research in Geographical and Environmental Education, 23:3, 213-227, 2014. DOI: $\underline{10.1080 / 10382046.2014 .927167 .}$

[8] Ertmer, P. A. , Schlosser, S. , Clase, K. , \& Adedokun, O. "The Grand Challenge: Helping Teachers Learn/Teach Cutting-Edge Science via a PBL Approach". Interdisciplinary Journal of Problem-Based Learning, 8(1), 2014. Available at: https://doi.org/10.7771/1541-5015.1407

[9] Jason Ravitz, Nate Hixson, Mary English, John Megendoller-“American Educational”. Using project based learning to teach 21 st century skills: Findings from a statewide initiative. PBL and 21st Century Skills. 2012.

[10] Tseng, KH., Chang, CC., Lou, SJ. et al. - "Attitudes towards science, technology, engineering and mathematics (STEM) in a project-based learning ( $\mathrm{PjBL}$ ) environment". Int $\mathrm{J}$ Technol Des Educ 23, 87-102, 2013. https://doi.org/10.10 07/s10798-011-9160-х
[11] Lih-Juan ChanLin - "Technology integration applied to project-based learning in science". Innovations in Education and Teaching International, 45:1, 55-65, 2008. DOI: $10.1080 / 14703290701757450$

[12] Beckett, G. - "Teacher and Student Evaluations of Project-Based Instruction". TESL Canada Journal, 19(2), 52-66, 2002. https://doi.org/10.18806/tesl.v19i2.929

[13] Drain, M. - "Justification of the dual-phase project-based pedagogical approach in a primary school technology unit". Design and Technology Education: an International Journal, 15(1), 7-14, 2010.

[14] Petersen, C., \& Nassaji, H. - "Project-based learning through the eyes of teachers and students in adult EFL classrooms", The Canadian Modern Language Review, 72(1), 13-39, 2016.

[15] Thomas, J. W, A review of research on project-based learning. Autodesk Foundation, 2000.

[16] Boaler, J. - "Open and closed mathematics: student experiences and understandings". Journal for Research in Mathematics Education, 29(1), 41-62, 1998.

[17] Boubouka, M., \& Papanikolaou, K. A. - Alternative assessment methods in technology enhanced project-based learning. International Journal of Learning Technology, 8(3), 263-296, 2013.

[18] 18-Holubova, R., - "Effective teaching methods project-based learning in physics", US-China Education Review, 12(5), 27-35, 2008.

[19] [18a] Buck Institute for Education - "What is project-based learning (PBL)", https://www.bie.org/about/what_pbl, $10 / 11 / 2018$

[20] Cocco, S., - "Student leadership development: the contribution of project-based learning". Unpublished Master's thesis. Royal Roads University, 2006.

[21] Kokotsaki, D., Menzies, V. and Wiggins, A. - "Project-based learning: a review of the literature", Improving schools, 19 (3), 267-277, 2016.

[22] Blumenfeld, P., Fishman, B.J., Krajcik, J., Marx, R.W. \& Soloway, E., - "Creating usable innovations in systemic reform: scaling up technology-embedded project-based science in urban schools", Educational Psychologist, 35(3), 149-164, 2000.

[23] Helle, L., Tynjälä, P. \& Olkinuora, E., - "Project-based learning in post-secondary education - theory, practice and rubber sling shots", Higher Education, 51, 287-314, 2006

[24] Adrian Stoica - "Using Math Projects in Teaching and Learning”, Procedia - Social and Behavioral Sciences, Vol. 180, 2015, pp. 702-708, ISSN 1877-0428,https://doi.org/10.1016/j.sbspro.2015.02.181.

[25] Barak, M., "From "doing" to "doing with learning": reflection on an effort to promote self-regulated learning in technological projects in high school", European Journal of Engineering Education, 37(1), 105-116, 2012.

[26] Bell, S., "Project-based learning for the 21st century: skills for the future", A Journal of Educational Strategies, Issues and Ideas, 83(2), 39-43, 2010. 
[27] Bender, W. N., - "Project-based learning: differentiating instruction for the 21st century". Corwin Press, 2012.

[28] Beckett, G. H., - "Teacher and student evaluations of Project-Based Instruction”, TESL Canada Journal, 19 (2), 2002.

[29] Markham, T., -"Project based learning: a bridge just far enough", Teacher Librarian, 39(2), 38-43, 2011.

[30] International Technology Education Association. Standards for technological literacy: Content for the study of technology. Virginia: Reston. 2000.

[31] Wrigley, T., - "Projects, stories and challenges: more open architectures for school learning”, In S. Bell, S. Harkness \& G. White (Eds), Storyline past, present and future, University of Strathclyde, 166-181, 2007.

[32] Brophy, J. -“Motivating students to learn”. Lawrence Erlbaum Associates, 2004.

[33] Kettanun, C. - "Project-based learning and its validity in a Thai EFL classroom", Procedia - Social and Behavioral Sciences, 192, $567-573,2015$.

[34] Mioduser, D., Betzer, N. - "The contribution of Project-based-learning to high-achievers' acquisition of technological knowledge and skills". Int J Technol Des Educ 18, 59-77, 2008. https://doi.org/10.1007/s10798-006 $-9010-4$

[35] Ginestié, J.- “ The Industrial Project Method in French Industry and in French Schools". International Journal of Technology and Design Education 12, 99, 2002. https://doi.org/10.1023/A:1015213511549

[36] Mettas, A., Constantinou, C. P. - "The technology fair: A project-based learning approach for enhancing problem solving skills and interest in design and technology education". International Journal of Technology and Design Education, Vol. 18, No. 1, p79-100, 2008.

[37] Duffy, T.M., - "Building lines of communication and a research agenda", In Tobias, S. and Duffy, T (Eds), Constructivist Instruction: Success or Failure, Routledge, 351-367, 2009.

[38] Naylor, S. and Keogh, B., - "Constructivism in classroom: Theory into practice", Journal of Science Teacher Education, 10, 93- 106, 1999.

[39] Fernandes, S., Mesquita, D., Flores, M. A., \& Lima, R. M. "Engaging students in learning: findings from a study of project-led education". European Journal of Engineering Education, 39(1), 55-67, 2014.

[40] Nguyen Huu Hau, Tran Viet Cuong, Tran Trung Tinh. "Students and teachers' perspective of the importance of arts in steam education in Vietnam." Journal of Critical Reviews 7.11, 2020, 666-671. Print. doi: $10.31838 /$ jcr.07.11.121

[41] Lam, S.-f., Cheng, R. W.-y., \& Choy, H. C. - "School support and teacher motivation to implement project-based learning. Learning and Instruction, 20(6), 487-497, 2010. . https://doi.org/10.1016/j.learninstruc.2009.07.003

[42] Dedouli, M., "Experiential learning-Possibilities of development through the framework of Flexible Zone", Inspection of Educational Subjects, 12 (6), 3- 8, 2001.

[43] Barak, M., - "From "doing" to "doing with learning": reflection on an effort to promote self-regulated learning in technological projects in high school", European Journal of Engineering Education, 37(1), 105-116, 2012. 